Prawne i ekonomiczne aspekty imigracji do Polski, red. Magdalena Butrymowicz, Piotr Kroczek, Kraków 2017, s. 125-144 (Biblioteczka Prawa, 2).

DoI: http://dx.doi.org/10.15633/9788374386340.08

Agnieszka Ogrodnik-Kalita

KATOLICKI UNIWERSYTET LUBELSKI JANA PAWŁA II

\title{
Zezwolenie na pobyt czasowy dla cudzoziemca małżonka obywatela Rzeczypospolitej Polskiej a wady oświadczenia woli przy zawarciu małżeństwa
}

Ustawa o cudzoziemcach ${ }^{1}$ wśród okoliczności uzasadniających udzielenie cudzoziemcowi zezwolenia na pobyt czasowy dla członka rodziny obywatela RP wymienia pozostawanie w uznawanym przez prawo RP związku małżeńskim z obywatelem $\mathrm{RP}^{2}$. Wskazana regulacja, chociaż wydaje się w pełni uzasadniona z punktu widzenia istoty i celu związku małżeńskiego, może rodzić niebezpieczeństwo zawierania przez cudzoziemców fikcyjnych małżeństw, mających na celu jedynie uzyskanie wskazanego zezwolenia. Taką sytuację bierze pod

1 Ustawa z dnia 12 grudnia 2013 r. o cudzoziemcach, Dz.U. z 2016 r., poz. 1990 z późn. zm., dalej: ustawa o cudzoziemcach, u.c.

2 Art. 158 ust. 1 pkt 1 u.c. 
uwagę ustawodawca, nakładając na organ prowadzący postępowanie w sprawie udzielenia zezwolenia na pobyt obowiązek ustalenia, czy związek małżeński został zawarty w celu obejścia ustawy. W ustawie wymienione zostały przykładowe okoliczności, które mogą wskazywać na zawarcie jedynie fikcyjnego związku małżeńskiego.

Jedynym przewidzianym $\mathrm{w}$ ustawie o cudzoziemcach skutkiem zawarcia małżeństwa wyłącznie w celu uzyskania zezwolenia na pobyt jest odmowa udzielenia wskazanego zezwolenia. Otwarte natomiast pozostaje pytanie o skutki takiego małżeństwa na gruncie prawa rodzinnego i środki, które mogłyby zostać zastosowane w celu jego kwestionowania. Próba odpowiedzi na nie wiąże się z koniecznością analizy terminu „małżeństwo pozorne”, którym posłużył się ustawodawca w ustawie o cudzoziemcach, a także z przedstawieniem okoliczności wskazujących na zawarcie małżeństwa w celu obejścia ustawy.

\section{Małżeństwo pozorne - uwagi terminologiczne}

Ustawodawca, regulując w ustawie o cudzoziemcach zagadnienia związane z zezwoleniem na pobyt dla cudzoziemca będącego małżonkiem obywatela RP, używa nie tylko opisowego sformułowania „Związek małżeński zawarty w celu obejścia przepisów ustawy”, ale co należy podkreślić - expressis verbis używa określenia „pozorne małżeństwo" (art. 169 ust. 2 pkt 7 u.c.). Ustawodawca nie sprecyzował jednak znaczenia tego terminu za pomocą definicji legalnej³.

Natomiast przy rozważaniu problematyki małżeństw zawieranych w celu obejścia przepisów ustawy w doktrynie i w orzecznictwie używane są różne terminy. Najczęściej pojawiają się określenia nawiązu-

3 Zob. P. Sadowski, Przeciwdziałanie i zwalczanie małżństw pozornych $w$ prawie polskim i brytyjskim, „Kwartalnik Prawa Publicznego” XII (2012) nr 4, s. 29. 
jące do pozornego charakteru takiego związku, chociaż także w tych przypadkach stosowana terminologia nie jest jednolita. Mirosław Nazar używa sformułowania „małżeństwa pozorowane”, precyzując, że chodzi o małżeństwa mieszane zawierane jedynie w celu legalizacji pobytu cudzoziemców w Polsce ${ }^{4}$. Małgorzata Pyziak-Szafnicka w tym kontekście posługuje się przede wszystkim pojęciem „małżeństw zawieranych dla pozoru"s. Autorka zauważa jednak, że potocznie takie małżeństwa określa się jako „białe” lub „papierowe”, a w języku prawniczym należałoby używać terminów „małżeństwa fikcyjne”, „pozorne” lub „zawierane dla pozoru”, „symulowane”. Ewa Kamarad używa natomiast opisowego określenia „składanie oświadczenia o wstąpieniu w związek małżeński na pozór"s.

W doktrynie podkreśla się, że zawarcie małżeństwa dla pozoru charakteryzuje brak zamiaru wywołania albo zamiar ograniczenia skutków prawnych, które ustawa łączy z dokonaniem tej czynności prawnej9. Krzysztof Pietrzykowski teoretycznie wyróżnił symulację dwustronną

4 Zob. J. Ignatowicz, M. Nazar, Prawo rodzinne, Warszawa 2016, s. 218.

5 M. Pyziak-Szafnicka, Europeizacja środków zwalczania oszustw w dziedzinie stanu cywilnego - przeciwdziałanie małżeństwom zawieranym dla pozoru, w: W kierunku europeizacji prawa prywatnego. Ksiegga pamiątkowa dedykowana Profesorowi Jerzemu Rajskiemu, red. A. Brzozowski, W. Kocot, K. Michałowska, Warszawa 2007, s. 619-629. Takiego określenia używa również K. Pietrzykowski, Wpływ wad oświadczenia woli na ważność matżeństwa, „Studia Prawnicze” (1980) nr 3, s. 148; K. Pietrzykowski, Wady oświadczenia, w: Kodeks rodzinny i opiekuńczy. Komentarz, red. K. Pietrzykowski, Warszawa 2015, s. 183.

6 Terminu „małżeństwo papierowe” używa J. Białocerkiewicz, Glosa do wyroku NSA $z$ dnia 27 kwietnia 2006 r., II OSK 1142/05, OSP $2007 \mathrm{nr} 2$ poz. 24.

7 Zob. M. Pyziak-Szafnicka, Europeizacja środków..., dz.cyt., s. 621.

8 E. Kamarad, Tryb zawarcia małżeństwa przez cudzoziemca w Polsce, w: Znad granicy ponad granicami. Ksiega dedykowana Profesorowi Dieterowi Martiny, red. M. Krzymuski, M. Margoński, Warszawa 2014, s. 108.

9 Zob. K. Pietrzykowski, Wpływ wad..., dz. cyt., s. 148; K. Pietrzykowski, Wady oświadczenia..., dz. cyt., s. 183. 
i symulację jednostronną. Ta pierwsza polega na świadomej sprzeczności między rzeczywistymi zamiarami obojga nupturientów a ich oświadczeniami woli złożonymi w obecności kierownika Urzędu Stanu Cywilnego (dalej: usc), a druga na braku zamiaru podjęcia pożycia małżeńskiego i założenia rodziny, występującego tylko u jednego z nupturientów ${ }^{10}$. Jako przykłady symulacji dwustronnej autor podaje m.in. zawarcie małżeństwa w celu uzyskania zezwolenia na pobyt cudzoziemca czy w celu nabycia praw do mieszkania, renty lub emerytury, przykładem symulacji jednostronnej jest zaś sytuacja, w której kobieta zawiera małżeństwo tylko w tym celu, aby ograniczyć się do biernego czekania na śmierć dogorywającego męża i nabycia po nim spadku ${ }^{11}$.

Użyte przez ustawodawcę w ustawie o cudzoziemcach określenie „małżeństwo pozorne” jednoznacznie kojarzy się z pozornością jako wadą oświadczenia woli uregulowaną w kodeksie cywilnym ${ }^{12}$. Zgod-

Zob. K. Pietrzykowski, Wpływ wad..., dz. cyt., s. 149. Kamarad rozróżnia oświadczenia o wstąpieniu w związek małżeński bez zamiaru wywołania skutków prawnych i w zamiarze wywołania innych skutków niż te przewidziane przez ustawodawcę. Autorka do tych drugich zalicza zawarcie związku małżeńskiego w celu nabycia obywatelstwa. Zob. E. Kamarad, Tryb zawarcia..., dz. cyt., s. 108.

11 Zob. K. Pietrzykowski, Wpływ wad..., dz. cyt., s. 149. Warto zauważyć, że problematyka małżeństw pozornych dotyczy nie tylko małżeństw zawieranych w celu obejścia przepisów ustawy o cudzoziemcach, ale może wynikać także z innych okoliczności życiowych, a rozważania Pietrzykowskiego na ten temat mają, jak się okazuje, charakter nie tylko czysto hipotetyczny. Taki wniosek wynika z badań Elżbiety Holewińskiej-Łapińskiej dotyczących unieważnienia małżeństwa w praktyce sądowej. Autorka wyróżniła tutaj przypadki żądania unieważnienia małżeństwa ze względu na przyczyny, których prawo polskie nie przewiduje. $\mathrm{W}$ jednym przypadku niesprawnemu mężowi chodziło o opiekę młodszej o 37 lat żony w zamian za jej materialne zabezpieczenie po śmierci męża (renta rodzinna, uprawnienie do mieszkania). Co interesujące, syn męża był zarazem partnerem życiowym żony. Zob. E. Holewińska-Łapińska, Unieważnienie małżenstwa w praktyce sądowej w 2010 r., „Studia i Analizy Sądu Najwyższego”, t. VI, LEX 2012. Ustawa z dnia 23 kwietnia 1964 r. Kodeks cywilny, Dz.U. z 2016 r., poz. 380 t.j. z późn. zm., dalej: kodeks cywilny, k.c. 
nie z art. 83 k.c. nieważne jest oświadczenie woli złożone drugiej stronie za jej zgodą dla pozoru. Oświadczenie woli jest pozorne, jeżeli strony są zgodne co do tego, że oświadczenie albo w ogóle nie ma wywołać żadnych skutków prawnych, albo wprawdzie ma wywołać skutek prawny, ale inny niż wynika z treści pozornej czynności praw$n^{1} j^{13}$. Stosowanie przez ustawodawcę w języku prawnym - w ustawie o cudzoziemcach - terminu oznaczającego jedną z cywilistycznych wad oświadczenia woli wydaje się niepożądane z punktu widzenia zasad techniki prawodawczej i może rodzić zarówno u samych małżonków, jak i prawników pokusę sięgania do przepisów kodeksu cywilnego w celu podważenia skutków małżeństwa zawartego w celu obejścia przepisów ustawy. Taki zabieg jest jednak niedopuszczalny ze względów, które zostaną szczegółowo przedstawione w kolejnych punktach. Pyziak-Szafnicka zauważa więc, że fakt, iż kwestia małżeństwa pozornego pojawia się w ustawie o cudzoziemcach, może być zaskakujący dla cywilisty ${ }^{14}$.

\section{Okoliczności wskazujące na zawarcie małżeństwa w celu obejścia ustawy}

Ustawa o cudzoziemcach precyzuje warunki wskazujące na potrzebę ustalenia, czy związek małżeński został zawarty w celu obejścia przez cudzoziemca przepisów ustawy ${ }^{15}$. Wymienione przez ustawodawcę

13 Zob. A. Wolter, J. Ignatowicz, K. Stefaniuk, Prawo cywilne. Zarys części ogólnej, Warszawa 2001, s. 305.

14 Zob. M. Pyziak-Szafnicka, Europeizacja środków..., dz.cyt., s. 627.

15 Zob. wyrok Naczelnego Sądu Administracyjnego w Warszawie z dnia 27 kwietnia 2006 r., II OSK 1142/05, OSP 2007 nr 2 poz. 24. Wskazane orzeczenie zostało wydane na gruncie nieobowiązującej już ustawy z dnia 27 kwietnia $2003 \mathrm{r}$. o cudzoziemcach, jednak pozostaje aktualne w swej zasadniczej treści. Warto za Janem Białocerkiewiczem zauważyć, że „zmieniające się błyskawicznie prawo 
okoliczności nie są jedynymi, które mogą wskazywać na jedynie fikcyjny charakter związku małżeńskiego, na co wskazuje użyty w art. 169 ust. 2 u.c. zwrot „W szczególności”.

Już prima facie można stwierdzić, że przykładowe okoliczności wymienione przez ustawodawcę świadczą o tym, że celem małżonków nie było stworzenie związku małżeńskiego jako wspólnoty obejmującej całe ich życie i polegającej na jak najściślejszym zespoleniu małżonków w płaszczyźnie duchowej, fizycznej i gospodarczej.

Organ prowadzący postępowanie w sprawie udzielenia cudzoziemcowi zezwolenia powinien w szczególności ustalić, czy jedno z małżonków przyjęło korzyść majątkową w zamian za wyrażenie zgody na zawarcie małżeństwa. Wyjątkiem jest sytuacja, w której przyjęcie takiej korzyści wynika ze zwyczaju ugruntowanego w danym państwie lub danej grupie społecznej.

Kolejną okolicznością mogącą wskazywać na fikcyjność małżeństwa jest niewypełnianie przez małżonków prawnych obowiązków wynikających z zawarcia małżeństwa. Prawa i obowiązki małżonków zostały unormowane w dziale iI tytułu I k.r.o. ${ }^{16} \mathrm{~W}$ analizowanym kontekście szczególne znaczenie będą miały obowiązki o charakterze niemajątkowym, wymienione w art. 23 k.r.o., czyli obowiązek wspólnego pożycia, wzajemnej pomocy i wierności oraz współdziałania dla dobra rodziny, którą małżonkowie przez swój związek założyli. Należy zauważyć, że ustalenie, czy wskazane obowiązki są przez małżonków wypełniane, powinno odbywać się w sposób taktowny i delikatny. Są one bowiem związane z najbardziej intymnymi sferami

o cudzoziemcach sprawia, że cudzoziemcowi trudno jest przewidzieć konsekwencje swojego działania bądź zaniechania” - J. Białocerkiewicz, Glosa do wyroku..., dz. cyt.

16 Ustawa z dnia 25 lutego 1964 r. Kodeks rodzinny i opiekuńczy, Dz.U. z 2015 r., poz. 2082 t.j., dalej: kodeks rodzinny i opiekuńczy, k.r.o. 
życia człowieka. Szczególne trudności będą wiązały się z ustaleniem więzi osobistej pomiędzy małżonkami, na którą składają się wspólnota duchowa i fizyczna.

Brak wspólnego zamieszkania lub nieprowadzenie wspólnego gospodarstwa domowego to kolejne fakty mogące wskazywać na fikcyjność zawartego związku małżeńskiego. Należy jednak podkreślić, że do takich sytuacji organ prowadzący postępowanie w sprawie powinien odnosić się z dużą dozą ostrożności. Chociaż podkreśla się, że możliwość zajmowania tego samego lokalu jest warunkiem skutecznego realizowania wspólnego pożycia małżeńskiego ${ }^{17}$, a wspólne zamieszkanie oraz prowadzenie gospodarstwa domowego najlepiej sprzyja prawidłowej realizacji spoczywających na małżonkach praw i obowiązków ${ }^{18}$, brak wspólnoty gospodarczej, przejawiający się w oddzielnym zamieszkiwaniu małżonków, nie musi zawsze stanowić, jak zaznacza Sąd Najwyższy, objawu rozkładu pożycia, jeżeli wynika z okoliczności niezależnych od małżonków lub z ich zgodnej woli uzasadnionej okolicznościami życiowymi ${ }^{19}$. Przykładem takiej sytuacji może być rozłączenie małżonków spowodowane wyjazdem służbowym czy pracą zarobkową małżonków w różnych odległych od siebie miejscowościach. Takie przypadki mogą mieć miejsce również w małżeństwach z cudzoziemcem i niekoniecznie muszą świadczyć o ich fikcyjności i chęci obejścia ustawy, ale również tutaj odstępstwa od reguły wspólnego zamieszkiwania małżonków powinny mieć charakter wyjątkowy i powinny być usprawiedliwione szczególnymi

17 Zob. A. Urbańska-Łukaszewicz, Wykonywanie prawa własności nieruchomości przez małżonków pozostających w ustawowym ustroju małżeńskim a ochrona rodziny, Warszawa 2016, s. 144. Wyrok Wojewódzkiego Sądu Administracyjnego w Warszawie z dnia 9 października 2009 r., V sA/Wa 889/o9, LEX nr 573064.

19 Uchwała Sądu Najwyższego z dnia 28 maja 1955 r., I CO 5/55, OsNCK 1955 nr 3 poz. 46. 
okolicznościami ${ }^{20}$. Z powyższego wynika, że organ prowadzący postępowanie w sprawie powinien dogłębnie badać wskazane przypadki i na pewno nie może mieć tutaj miejsca automatyzm rozstrzygnięcia. Warto zaznaczyć, że ustawodawca rozróżnia w rozważanym kontekście brak wspólnego zamieszkiwania od nieprowadzenia wspólnego gospodarstwa domowego. W związku z tym możliwa jest sytuacja, w której małżonkowie zamieszkujący wspólnie nie będą prowadzili wspólnego gospodarstwa domowego. Będą na to wskazywały takie fakty jak: prowadzenie oddzielnych budżetów domowych, brak wspólnego przygotowywania i spożywania posiłków czy faktyczne zajmowanie oddzielnych pomieszczeń we wspólnie zamieszkiwanym domu.

Ustawodawca, wśród okoliczności mogących wskazywać na chęć obejścia przez małżonków ustawy o cudzoziemcach, wymienia także sytuację, w której małżonkowie nie spotkali się przed zawarciem małżeństwa. Fikcyjny charakter małżeństwa wydaje się w takich przypadkach szczególnie prawdopodobny. Decyzja o zawarciu małżeństwa należy do jednych z najważniejszych decyzji w życiu człowieka i trudno wyobrazić sobie sytuację, w której dotyczy ona osób, które wcześniej się nie spotkały. Co prawda ustawodawca w obecnym stanie prawnym nie normuje instytucji zaręczyn ${ }^{21}$, jednak nie sposób nie doceniać wpływu etapu poprzedzającego zawarcie małżeństwa na istnienie i jakość późniejszych relacji pomiędzy małżonkami.

20 Wyrok Wojewódzkiego Sądu Administracyjnego w Warszawie z dnia 27 października 2009 r., V sA/Wa 911/o9, LEX nr 551265.

21 Kodeks rodzinny i opiekuńczy przewiduje jedynie w art. 4 okres 1 miesiąca wyczekiwania na zawarcie małżeństwa. Tadeusz Smyczyński zauważa, że ma on zapobiegać decyzjom pochopnym i nieprzemyślanym. Autor zauważa również, że czas ten zastępuje w pewnym stopniu instytucję zaręczyn. Zob. T. Smyczyński, Prawo rodzinne i opiekuńcze, Warszawa 2016, s. 31. Jednak kierownik usc może zezwolić na zawarcie małżeństwa przed upływem tego terminu, jeżeli przemawiają za tym ważne względy. 
Organ prowadzący postępowanie w sprawie powinien ponadto ustalić, czy okoliczności sprawy wskazują na to, że małżonkowie nie mówią językiem zrozumiałym dla obojga lub też nie są zgodni co do dotyczących ich danych osobowych i innych istotnych okoliczności, a także czy jedno z małżonków - lub oboje - w przeszłości zawierali już pozorne małżeństwa.

Warto zauważyć, że szczególnej uwagi będą wymagały przypadki, w których występuje „kumulacja” wskazanych powyżej okoliczności, czyli sytuacja, w której małżonkowie nigdy razem nie zamieszkiwali, nie wypełniają obowiązków małżeńskich i nie porozumiewają się $\mathrm{w}$ tym samym języku ${ }^{22}$.

W celu dokonania wskazanych powyżej ustaleń organ prowadzący postępowanie może, na podstawie art. 169 ust. 4 u.c., zwrócić się z wnioskiem do komendanta oddziału straży granicznej lub komendanta placówki straży granicznej, właściwego ze względu na miejsce pobytu cudzoziemca, o przeprowadzenie wywiadu środowiskowego. Możliwość skorzystania z pomocy funkcjonariuszy straży granicznej nie wyłącza w tym zakresie kompetencji organu prowadzącego postępowanie. W związku z tym nie ma przeszkód, aby organ prowadzący postępowanie podejmował czynności dowodowe, które umożliwiają dokonanie ustaleń objętych wywiadem środowiskowym ${ }^{23}$. Należy podkreślić, że czynności dowodowe czy to funkcjonariuszy straży granicznej, czy organu prowadzącego postępowanie powinny być przeprowadzane z poszanowaniem prawa do prywatności małżonków,

22 Tak np. w stanach faktycznych będących podstawą wyroków Wojewódzkiego Sądu Administracyjnego w Warszawie z dnia 27 października 2009 r., V sA/ Wa 911/09, LEX nr 551265; z dnia 9 października 2009 r., V SA/Wa 889/o9, LEX nr 573064; z dnia 30 stycznia 2015 r., IV SA/Wa 2478/14, LEX nr 1753761.

23 Zob. J. Chlebny, Zezwolenie na pobyt czasowy dla członków rodzin obywateli Rzeczypospolitej Polskiej oraz członków rodzin cudzoziemców, w: Ustawa o cudzoziemcach. Komentarz, red. J. Chlebny, Warszawa 2015, s. 492. 
których dotyczą. Warto pamiętać, że ustalenia są związane ze sprawami intymnymi i osobistymi, często należącymi do sfery życia prywatnego czy nawet intymnego człowieka ${ }^{24}$. Ingerencja w te obszary życia małżonków powinna mieć miejsce tylko w zakresie usprawiedliwionym celami prowadzonego postępowania ${ }^{25}$.

Należy jednak podkreślić, że dojście przez organ prowadzący postępowanie w sprawie do wniosku, że w danym małżeństwie występuje jedna bądź kilka z wymienionych w art. 169 ust. 2 u.c. sytuacji, nie uzasadnia samo przez się stwierdzenia, że małżeństwo zostało zawarte w celu obejścia przepisów o udzielaniu zezwolenia na pobyt czasowy. Przepis ten wymienia jedynie okoliczności uzasadniające potrzebę ustalenia, czy małżeństwo nie zostało zawarte przez cudzoziemca w celu obejścia przepisów o udzielaniu zezwoleń. Stwierdzenie ich występowania nie jest tożsame z ustaleniem, że związek małżeński został zawarty w celu obejścia wskazanych przepisów, lecz jedynie

24 Dokładnie na temat wywiadu środowiskowego przeprowadzanego przez funkcjonariuszy Straży Granicznej zob. A. Wróblewska-Zgórzak, Prawne aspekty zawierania małżeństw polsko-cudzoziemskich, „Stowarzyszenie Interwencji Prawnej. Analizy, Raporty, Ekspertyzy" (2010) nr 1, s. 14-16, https://interwencjaprawna. pl/docs/ARE-110-malzenstwa-cudzoziemcy.pdf (20.11.2015). Obecnie sposób i tryb przeprowadzania wywiadu środowiskowego w omawianych sprawach reguluje Rozporządzenie Ministra Spraw Wewnętrznych z dnia 11 lutego 2015 r. w sprawie wywiadu środowiskowego przeprowadzanego przez funkcjonariuszy Straży Granicznej w postępowaniach prowadzonych wobec cudzoziemców, Dz.U. Z 2015 r., poz. 274.

25 Znamienne w tym kontekście są spostrzeżenia Aleksandry Wróblewskiej-Zgórzak. Autorka zauważa, że z jej praktyki zawodowej wynika, że „niejednokrotnie cudzoziemcy skarżyli się na to, że funkcjonariusze w toku czynności poddają oglądowi i ocenie ich prywatne rzeczy, takie jak np. schowki na bieliznę w celu sprawdzenia czy znajduje się tam męska/damska bielizna, kosze na ubrania przeznaczone do prania lub pościel i miejsce do spania. Zabiegi te miały na celu ustalenie, czy dany cudzoziemiec bądź cudzoziemka utrzymują intymne kontakty ze swym współmałżonkiem, co wydaje się im upokarzające" - A. Wróblewska-Zgórzak, Prawne aspekty..., dz. cyt., s. 16. 
uzasadnia przeprowadzenie postępowania umożliwiającego ustalenie, czy małżeństwo zostało zawarte w tym celu ${ }^{26}$.

\section{Skutki zawarcia związku małżeńskiego w celu obejścia ustawy}

Należy zaznaczyć, że małżeństwo pozorne jest ważne od chwili jego zawarcia i w związku z tym rodzi takie same prawa i obowiązki, jak gdyby małżonkowie zawarli małżeństwo z pełną wolą prowadzenia pożycia małżeńskiego ${ }^{27}$. W przypadku zawarcia małżeństwa jedynie w celu uzyskania zezwolenia na pobyt małżonkowie nie będą mogli żądać jego unieważnienia ${ }^{28}$. Wady oświadczenia woli przy zawarciu

26 Zob. wyrok Naczelnego Sądu Administracyjnego w Warszawie z dnia 27 kwietnia 2006 r., II OSK 1142/05, OSP 2007 nr 2 poz. 24.

27 Orzeczenie Sądu Najwyższego z dnia 2 maja 1959 r., II CR 219/58, „Ruch Prawniczy Ekonomiczny i Socjologiczny" (1960) nr 3, s. 286; K. Piasecki, Zawarcie małżeństwa, w: Kodeks rodzinny i opiekuńczy. Komentarz, red. K. Piasecki, Warszawa 2009, s. 105; P. Sadowski, Przeciwdziałanie i zwalczanie..., dz. cyt., s. 48.

28 Oczywiście brak takiej możliwości ma miejsce przy założeniu, że przy składaniu oświadczeń o wstąpieniu w związek małżeński tylko dla pozoru nie wystąpiła żadna z wad oświadczenia woli przy zawarciu małżeństwa. Prima facie w takiej sytuacji najbardziej prawdopodobny wydaje się błąd co do tożsamości drugiej strony. Osoby zamierzające zawrzeć związek małżeński jedynie w celu uzyskania zezwolenia z oczywistych względów nie znają się tak dobrze, jak nupturienci w zwyczajnych okolicznościach zawierania małżeństwa. Istotne jest jednak, że w przypadku błędu jako wady oświadczenia woli przy zawarciu małżeństwa chodzi o „identyczność w znaczeniu bycia tym samym fizycznie podmiotem, z którym małżeństwo miało być zawarte" (J. Ignatowicz, M. Nazar, Prawo rodzinne, dz. cyt., s. 216). Zakres zastosowania art. $15^{1} \$ 2$ k.r.o. jest więc bardzo wąski. Błąd co do tożsamości fizycznej polega na tym, że osoba A zamierza poślubić osobę $\mathrm{B}$, a w rzeczywistości zawiera małżeństwo $\mathrm{z}$ osobą $\mathrm{C}$ - i taka sytuacja może ewentualnie pojawić się w odniesieniu do bliźniaków, a także $\mathrm{w}$ razie zawarcia małżeństwa przez pełnomocnika $\mathrm{z}$ osobą o tym samym imieniu i nazwisku co osoba wskazana w pełnomocnictwie (zob. T. Smyczyński, Prawo rodzinne..., dz. cyt., s. 53; autor dopuszcza jednak w pewnych sytuacjach 
małżeństwa zostały uregulowane w sposób odrębny i odmienny od wad oświadczenia woli w prawie cywilnym ${ }^{29}$. Art. 17 k.r.o. w sposób jednoznaczny przesądza, że małżeństwo może być unieważnione tylko z przyczyn przewidzianych $\mathrm{w}$ tym akcie prawnym, tj. z powodu przeszkód małżeńskich (art. 10-15 k.r.o.), wad oświadczenia woli (art. $15^{1}$ k.r.o.) lub wad pełnomocnictwa (art. 16 k.r.o.) ${ }^{30}$. Małżeństwo nie może więc być unieważnione $\mathrm{z}$ innych przyczyn niż wskazane przez ustawodawcę, gdyż powody jego unieważnienia są:

(...) enumeratywnie i wyczerpująco określone w art. 10-16 k.r.o. i ich zmiana wymaga interwencji ustawodawcy. Nie jest więc

możliwość unieważnienia małżeństwa w przypadku błędu co do tzw. tożsamości cywilnej). W związku z tak wąskim ujęciem błędu jako wady oświadczenia woli przy zawarciu małżeństwa Mirosław Nesterowicz zauważa, że art. $15^{1} \$ 2$ k.r.o. to „martwy przepis, beż żadnego znaczenia, który być może znajdzie zastosowanie raz na kilkadziesiąt lat. Jest przy tym dość jednoznaczny, nie widać uzasadnienia do jego rozszerzającej interpretacji przez orzecznictwo" - M. Nesterowicz, Błąd co do osoby jako przyczyna unieważnienia małżeństwa (uwagi de lege ferenda), „Państwo i Prawo” (2009) nr 4, s. 30.

Jednak w przypadku zawarcia małżeństwa jedynie w celu uzyskania zezwolenia prawdopodobna wydaje się sytuacja, w której obywatel polski, zamierzając zawrzeć tylko fikcyjne małżeństwo z cudzoziemcem A, w rzeczywistości zawiera małżeństwo $\mathrm{z}$ cudzoziemcem B, gdyż cudzoziemiec A np. z powodu choroby poprosił cudzoziemca B o „zastępstwo”. Jedną z okoliczności wskazujących na fikcyjny charakter związku małżeńskiego jest przecież przypadek, w którym małżonkowie nie spotkali się przed zawarciem małżeństwa. W takiej sytuacji obywatel Polski nie wie, że zawiera małżeństwo nie z tym cudzoziemcem, z którym zamierzał i od którego np. przyjął zapłatę, a kierownik usc na podstawie samego dowodu tożsamości może nie zorientować się, że małżeństwo zawiera nie ta osoba, która powinna. Należałoby jednak zastanowić się: czy można być w błędzie, czyli w mylnym przekonaniu, co do okoliczności, której się nie zna? Odpowiedź na tak postawione pytanie wydaje się negatywna. Zob. J. M. Łukasiewicz, Wady oświadczenia o wstąpieniu w związek małżeński, w: Instytucje prawa rodzinnego, red. J. M. Łukasiewicz, LEX 2013.

30 Zob. W. Borysiak, Zawarcie matżeństwa, w: Kodeks rodzinny i opiekuńczy. Komentarz, red. J. Wierciński, Warszawa 2014, s. 182. 
możliwe sięganie do przepisów, które znajdują się w innych działach prawa i przewidują określone przyczyny nieważności czynności prawnych $^{31}$.

Dotyczy to również, jak już wskazywano, wady oświadczenia woli w postaci pozorności. Jak wskazuje Witold Borysiak:

(...) złożenie za wspólnym porozumieniem przez kobietę i mężczyznę oświadczeń woli o wstąpieniu w związek małżeński bez zamiaru wywołania skutków prawnych właściwych dla małżeństwa (...) jest pozbawione wpływu na istnienie małżeństwa. Jest to niezależne od tego, czy „właściwy cel” złożenia takich oświadczeń był objęty wolą obojga lub jedynie jednego z małżonków ${ }^{32}$.

Taki zamiar nie ma wpływu na istnienie lub możliwość unieważnienia małżeństwa ${ }^{33}$. Stosowanie art. 83 k.c. do oświadczenia woli o wstąpieniu w związek małżeński jest oczywiście wykluczone ${ }^{34}$.

Niewymienienie wady oświadczenia woli w postaci pozorności $\mathrm{w}$ art. $15^{1}$ k.r.o. wyraźnie wyłącza więc możliwość powołania się na nią jako na podstawę unieważnienia małżeństwa. Pominięcie pozorności wśród wad oświadczenia woli przy zawarciu małżeństwa jest akceptowane przez dominującą część doktryny ${ }^{35}$. Jerzy Strzebinczyk podkreśla nawet, że takie rozwiązanie to „niezwykle trafne posunięcie ustawodawcy" ${ }^{36}$. Autor zauważa, że dopuszczenie możliwości unie-

31 W. Borysiak, Zawarcie małżeństwa, dz. cyt.

32 W. Borysiak, Zawarcie małżeństwa, dz. cyt., s. 172.

33 Zob. W. Borysiak, Zawarcie małżeństwa, dz. cyt., s. 173.

34 Zob. K. Pietrzykowski, Wady oświadczenia..., dz.cyt., s. 183.

35 Zob. J. Ignatowicz, M. Nazar, Prawo rodzinne, dz. cyt., s. 218; M. Pyziak-Szafnicka, Europeizacja środków..., dz. cyt., s. 627.

36 J. Strzebinczyk, Prawo rodzinne, Warszawa 2013, s. 100. 
ważnienia małżeństwa z powodu pozorności powodowałoby poważne niebezpieczeństwo wykorzystywania jej wyłącznie w celu łatwego zniweczenia węzła małżeńskiego z obejściem przepisów rozwodowych, gdyż wystarczyłoby udowodnienie przez małżonków, że złożyli oświadczenia o wstąpieniu w związek małżeński wyłącznie dla pozoru, czyli bez zamiaru zawarcia małżeństwa ${ }^{37}$. Spostrzeżenia autora pozostają oczywiście aktualne także w kontekście małżeństw zawieranych w celu obejścia przepisów ustawy o cudzoziemcach, chociaż sam autor, jak zaznacza, postrzega problem wyłącznie teoretycznie.

Błędne w związku z tym jest stanowisko Krystyny Gromek, które dopuszcza stosowanie przepisów kodeksu cywilnego w drodze analogii. Autorka twierdzi, że ze względu na dużą enigmatyczność art. $15^{1}$ k.r.o., jak i zbieżność terminologiczną wad oświadczenia woli z k.r.o. i z art. $82-88$ k.c. - art. $15^{1}$ k.r.o. może i powinien być interpretowany w kontekście przepisów kodeksu cywilnego dotyczących wad oświadczenia woli ${ }^{3}$. Nie wydaje się również zasadne zdanie Elżbiety Holewińskiej-Łapińskiej, która co prawda zaznacza, że w przypadku zawarcia małżeństwa fikcyjnego brak jest podstaw do jego unieważnienia, ale jednocześnie takie rozwiązanie uważa za istotną niedoskonałość obowiązujących rozwiązań prawnych ${ }^{39}$.

Należy podkreślić, że brak możliwości unieważnienia małżeństwa zawartego w celu obejścia przepisów ustawy o cudzoziemcach powinien zniechęcać obywateli polskich do ich zawierania ${ }^{40}$. Brak

37 Zob. J. Strzebinczyk, Prawo rodzinne, dz. cyt. Na temat postrzegania instytucji unieważnienia małżeństwa jako narzędzia w obchodzeniu przepisów prawa rozwodowego zob. M. Kosek, Powództwo prokuratora w sprawach niemajątkowych z zakresu prawa rodzinnego, Warszawa 2016, s. 261.

38 Zob. K. Gromek, Kodeks rodzinny i opiekuńczy. Komentarz, Warszawa 2016, s. 96.

39 Zob. E. Holewińska-Łapińska, Unieważnienie małżeństwa..., dz. cyt.

40 Piotr Sadowski zwrócił uwagę na konieczność rozważenia zasadności wprowadzenia możliwości informowania przez kierownika usc o konsekwencjach 
możliwości unieważnienia takiego małżeństwa oznacza bowiem, że nie nastąpią skutki unieważnienia, tzn. powrót małżonków do ich poprzedniego stanu cywilnego, ustanie powinowactwa czy powrót małżonka do poprzedniego nazwiska ${ }^{41}$. Takie rozwiązanie należy ocenić zdecydowanie pozytywnie i uznać za istotny atrybut przyjętej regulacji. Trudno wyobrazić sobie sytuację, w której następuje przyjęcie korzyści majątkowej za zawarcie małżeństwa z cudzoziemcem i małżeństwo zostaje zawarte, a następnie małżonek, który przyjął korzyść majątkową, może żądać unieważnienia małżeństwa. Dopuszczenie takiej możliwości stałoby w oczywistej sprzeczności z istotą wad oświadczenia woli przy zawarciu małżeństwa, których uwzględnienie w kodeksie rodzinnym i opiekuńczym jako jednej z przyczyn unieważnienia małżeństwa miało m.in. gwarantować pełną i swobodną zgodę stron $^{42}$. Warto zauważyć, że jeszcze przed regulacją wad oświadczenia

prawnych związanych z zawieraniem małżeństwa z cudzoziemcem. Kierownik powinien w takim wypadku poinformować w sposób obiektywny i wyczerpujący o możliwych negatywnych skutkach, które mogą mieć miejsce, gdy okaże się, że małżeństwo ma charakter pozorny. Autor podkreśla, że obecnie małżonek, który w dobrej wierze zawarł małżeństwo z cudzoziemcem, nie jest w żaden sposób chroniony i prawo nie przewiduje ułatwień w zakończeniu takiego związku. Autor rozważa również przyznanie kierownikom usc możliwości wydania decyzji o odmowie rejestracji małżeństwa w przypadku powzięcia wątpliwości co do rzeczywistych intencji małżonków. Zob. P. Sadowski, Przeciwdziałanie i zwalczanie..., dz. cyt., s. 48-49. Należy jednak zaznaczyć, że w przypadku przyjęcia zgodnych oświadczeń nupturientów przez kierownika usc nawet niesporządzenie aktu małżeństwa nie podważa jego istnienia i ważności. Akt małżeństwa zawartego w formie cywilnej ma bowiem charakter deklaratywny. Zob. T. Smyczyński, Prawo rodzinne..., dz. cyt., Warszawa 2016, s. 32; A. Czajkowska, Rodzaje aktów stanu cywilnego, w: Prawo o aktach stanu cywilnego z komentarzem. Przepisy wykonawcze i związkowe oraz wzory dokumentów, red. A. Czajkowska, Warszawa 2015, s. 194.

41 Na temat skutków unieważnienia małżeństwa zob. T. Smyczyński, Prawo rodzinne..., dz. cyt., s. 58.

42 Zob. T. Smyczyński, Nowelizacja prawa małżeńskiego, „Państwo i Prawo” (1999) nr 1, s. 30 . 
woli w kodeksie rodzinnym i opiekuńczym Pietrzykowski twierdził, że postulat wprowadzenia zakazu zawierania małżeństw pozornych nie jest uzasadniony, gdyż zgoda na zawarcie takiego małżeństwa jest właśnie pełna i swobodna ${ }^{43}$.Wskazane ratio legis przepisów o wadach oświadczenia woli przy zawarciu małżeństwa nabiera tutaj szczególnego znaczenia. Należy podkreślić, że przepisy o wadach oświadczenia woli, w tym także o wadach oświadczenia woli przy zawarciu małżeństwa, chronią autonomię woli podmiotów prawa cywilnego ${ }^{44}$. Przy zawarciu małżeństwa taką ochroną objęta jest autonomia małżonków. Dyskwalifikowane są bowiem takie oświadczenia, które nie zostały złożone w sposób w pełni wolny, gdyż ktoś dokonał niedopuszczalnej ingerencji w swobodę decyzyjną małżonka ${ }^{45}$.

Magdalena Wilejczyk trafnie zauważa, że przepisy o wadach oświadczenia woli w równym stopniu chronią także autentyczność działających osób, co zdaniem autorki odnosi się przede wszystkim do regulacji błędu i braku świadomości, gdyż w tych przypadkach nie chodzi o to, że została naruszona swoboda decyzyjna jakiegoś podmiotu, lecz przede wszystkim o to, że złożone w takich warunkach oświadczenie woli nie odpowiada temu, co dana osoba oświadczyłaby, gdyby nie działała przy istnieniu tych nieprawidłowości ${ }^{46}$. Wskazane stanowisko pozostaje w pełni aktualne w kontekście błędu co do tożsamości drugiego z nupturientów i stanu wyłączającego świadome

Zob. K. Pietrzykowski, Wpływ wad..., dz.cyt., s. 149. Jan Winiarz, również przed regulacją wad oświadczenia woli w kodeksie rodzinnym i opiekuńczym, podkreślał, że „sytuacja na tle pozorności różni się w sposób istotny od objętej przepisem art. 82 k.c. Na jej tle występuje świadome powzięcie określonej woli, od której świadomie odbiega treść jej uzewnętrznienia" - J. Winiarz, Prawo rodzinne, Warszawa 1994, s. 45.

44 Zob. M. Wilejczyk, Zagadnienia etyczne części ogólnej prawa cywilnego, Warszawa 2014, s. 300.

45 Zob. M. Wilejczyk, Zagadnienia etyczne..., dz.cyt.

46 Zob. M. Wilejczyk, Zagadnienia etyczne..., dz. cyt., s. 301. 
wyrażenie woli przy zawarciu małżeństwa, gdyż w takich wypadkach oświadczenie o wstąpieniu w związek małżeński jest aktem nieautentycznym, zniekształconym i nieodpowiadającym zamiarowi składającej go osoby ${ }^{47}$.

Celem unormowania w kodeksie rodzinnym i opiekuńczym wad oświadczenia woli przy zawarciu małżeństwa jest więc na pewno ochrona autonomii i autentyczności oświadczeń małżonków. Świadczy o tym chociażby bardzo wąskie ukształtowanie legitymacji czynnej w sprawach o unieważnienie małżeństwa z powodu wad oświadczenia woli $^{48}$. Taką legitymację posiada bowiem jedynie małżonek, który złożył oświadczenie dotknięte wadą. Natomiast cywilistyczna wada pozorności nie odpowiada klasycznemu ujęciu wad oświadczenia woli, ponieważ w tym przypadku nie chodzi o ochronę osoby, która złożyła swoje oświadczenie w nietypowych warunkach, lecz:

(...) istotą regulacji jest tu dyskwalifikacja czynności prawnej ze względu na to, że została ona dokonana w celu wprowadzenia w błąd innych osób; sankcja nieważności nie ma tu więc charakteru ochronnego, lecz dezaprobujący. Jej celem jest wyeliminowanie z obrotu czynności nieetycznej $(\ldots)^{49}$.

W przypadku zawarcia małżeństwa w celu uzyskania zezwolenia żaden z małżonków nie zasługuje na ochronę, a „eliminacja z obrotu czynności nieetycznej”, jaką jest niewątpliwie zawarcie małżeństwa

47 Zob. M. Wilejczyk, Zagadnienia etyczne..., dz.cyt., s. 300.

48 Janusz Gajda podkreśla, że w przypadku wad oświadczenia woli o wstąpieniu w związek małżeński ustawodawca dokonał zawężenia kręgu podmiotów uprawnionych do wystąpienia z żądaniem unieważnienia małżeństwa. Zob. J. Gajda, Postępowanie w sprawie o unieważnienie malżenstwa, w: System Prawa Prywatnego. Prawo rodzinne i opiekuńcze, t. 11, red. T. Smyczyński, Warszawa 2014, s. 202.

49 M. Wilejczyk, Zagadnienia etyczne..., dz. cyt., s. 302. 
w celu obejścia przepisów ustawy, byłaby faktycznie nagrodą dla małżonków, którzy w przypadku uzasadnionego zastosowania sankcji przewidzianej w ustawie o cudzoziemcach, jaką jest odmowa udzielenia zezwolenia, zapewne dążą do jak najszybszego „unicestwienia” fikcyjnego małżeństwa.

Pozostaje do rozstrzygnięcia zagadnienie procesowych następstw sytuacji, w której małżonek, czy jakakolwiek inna osoba, domaga się unieważnienia małżeństwa, powołując się na pozorność oświadczeń o wstąpieniu w związek małżeński. W takim przypadku powództwo powinno zostać oddalone $\mathrm{z}$ uwagi na brak ustawowego powodu unieważnienia małżeństwa.

Jedynym przewidzianym przez ustawodawcę skutkiem zawarcia związku małżeńskiego w celu obejścia ustawy jest udzielenie cudzoziemcowi odmowy zezwolenia na pobyt czasowy lub stały (art. 165 ust. 1 u.c.). Jeśli więc motywem zawarcia małżeństwa było jedynie uzyskanie zezwolenia, wówczas konsekwencje tego mogą przybrać jedynie formę administracyjną bez możliwości unieważnienia małżeństwa ${ }^{50}$. Następstwem takiej decyzji będzie więc właściwie separacja faktyczna małżonków. Celem udzielenia zezwolenia na pobyt czasowy lub stały dla cudzoziemca będącego małżonkiem obywatela polskiego jest bowiem ochrona życia rodzinnego cudzoziemców ${ }^{51}$, a fikcyjne małżeństwo na taką ochronę nie zasługuje. Ocena organu, że związek małżeński cudzoziemca został zawarty w celu obejścia przepisów ustawy, nie ma żadnego znaczenia dla jego ważności i wywołania przez ten związek innych skutków przewidzianych prawem ${ }^{52}$. Taka konstatacja wywołuje wyłącznie skutki w zakresie określonym

50 Zob. M. Andrzejewski, Prawo rodzinne i opiekuńcze, Warszawa 2010, s. 53.

51 Zob. J. Chlebny, Zezwolenie na pobyt..., dz. cyt., s. 461.

52 Zob. J. Chlebny, Zezwolenie na pobyt..., dz. cyt., s. 491. 
w przepisach ustawy o cudzoziemcach i odnosi się wyłącznie do prawa pobytu cudzoziemca na terytorium Polski.

\section{Uwagi końcowe}

Warto jeszcze raz stanowczo podkreślić, że obecne rozwiązanie - uniemożliwiające unieważnienie małżeństwa zawartego w celu legalizacji pobytu cudzoziemca w Polsce - zasługuje na aprobatę. Zgoda nupturientów jest w takim przypadku pełna i swobodna, nie jest więc tutaj potrzebna ochrona przewidziana w przypadku wad przy składaniu oświadczeń o wstąpieniu w związek małżeński. Takie postępowanie jest ponadto naganne $z$ etycznego punktu widzenia.

Biorąc powyższe pod uwagę, należy zaznaczyć, że jedyną drogą umożliwiającą małżonkom, którzy zawarli małżeństwo wyłącznie w celu uzyskania przez cudzoziemca zezwolenia na pobyt czasowy, unicestwienie jego skutków będzie postępowanie o rozwód ${ }^{53}$. Jednak również w tym wypadku konieczne będzie spełnienie przesłanek rozwodowych z art. 56 k.r.o., w tym przesłanki pozytywnej, jaką jest zupełny i trwały rozkład pożycia małżeńskiego. Wydaje się jednak, że w tych okolicznościach, gdy małżonkowie w ogóle nie podjęli wspólnego pożycia, stwierdzenie jego rozkładu, cechującego się zupełnością i trwałością, nie będzie nastręczało trudności. Konieczne będzie jednak ujawnienie przed sądem rzeczywistych motywów zawarcia związku małżeńskiego i celu, jakim kierowali się małżonkowie. W przeciwnym wypadku, jeżeli pozew o rozwód zostanie wniesiony w krótkim czasie od zawarcia małżeństwa, udowodnienie przede wszystkim trwałości rozkładu pożycia może jednak rodzić pewne trudności.

53 Zob. J. Winiarz, J. Gajda, Prawo rodzinne, Warszawa 2001, s. 57. 


\section{Summary}

A temporary residence permit for the family member of the polish citizen and defects in declaration of intent during entering into marriage

Marriage between a foreigner and a citizen of Poland is one of the conditions of a temporary residence permit for the family member of the Polish citizen. The indicated regulation can cause a danger of marriages of convenience concluded between the foreigner and the Polish citizen, which are concluded only for getting the permit. Therefore, the body conducting the proceedings for granting the temporary residence permit, is obliged to determine whether a marriage was concluded in order to circumvent the law. The law on foreigners gives examples of circumstances, which may indicate a fictional marriage. The subject of the article is analysis of indicated condition of the temporary residence permit in the context of defects in the declaration of intent during entering into marriage. Defects in declaration of intent during entering into marriage were regulated separately and differently from the civil law. The legislator did not provide the ostensible nature of declaration of intent among them. The only effect of the marriage in order to obtain the temporary residence permit is the refusal of the permit.

Key words: foreigner, residence permit, fictional marriage, civil law 